\title{
2 Crossover Voting Before the Blanket: Primaries Versus Parties IN CALIFORNIA HISTORY
}

\author{
Brian J. Gaines \\ Wendy K. Tam Cho*
}

\begin{abstract}
The passage of Proposition 198, which brought the blanket primary to California, was in plain defiance of the preferences and advice of most elites, including, notably, both of the major political parties. In this chapter, we briefly trace the chronology of primary elections in the Golden State, with an emphasis on how they have been intertwined, from the beginning, with an anti-party spirit. We thus orient the blanketprimary, as delivered by direct democracy, in a distinctive state political culture of independence from, and ambivalence or even hostility towards, political parties. We then focus on the parallels between voting options under the brand new blanket primary law and those presented in the mid-twentieth century during the multi- (or "cross-") filing era, in search of an appropriate historical baseline against which to place 1998 and future elections.
\end{abstract}

The easy passage of Proposition 198, the Open Primary Initiative, can be understood as yet another instance of defiant populism, wherein a healthy majority of California voters thumb their noses at elite advice to embrace a measure whose appeal is simple and whose alleged flaws evidently do not trouble many. As such, Proposition 198 followed in the wake of numerous other initiatives, the most famous of which is probably still 1978's Proposition 13 , a property-tax-freezing measure that is sometimes said to have set off a nation-wide "tax revolt" (see, e.g., Kettl 1992, 58, 152). But the change from a closed to a fully open primary originated in something more specific than populism: it was clearly an act of anti-party populism, which thus tapped a

\footnotetext{
* Our thanks to Bruce Cain, Michael Caldwell, Christophe Crombez, and Elisabeth Gerber for helpful suggestions, and to Lloyd Gruber for extraordinary assistance with locating primary sources.
} 
sentiment that dates from the founding of the country and that has been especially strong in California.

The blanket primary is a novelty in California's electoral history, but it is closely related to a prior innovation in primary electoral law, cross-filing (a.k.a. multi-filing). Amongst A merican states, only California and N ew York have had long and plentiful experience with allowing candidates to enter multiple party primaries, and thereby possibly to secure several party nominations for the general election. California's multi-filing history and $\mathrm{New}$ York's ongoing experiment with this practice have produced rather different outcomes. In N ew York, a right-wing Conservative party, a left-wing Liberal party, and the occasional very small special-interest party have all become interesting supporting players, whose presence acts as a centrifugal force on candidates from the major parties. Most often, the identifiable blocs of votes cast for fusion candidates under the Conservative and/ or Liberal lines simply inflate or deflate existing Republican-Democratic margins of victory or defeat. On occasion, though, they provide the critical difference. ${ }^{1}$ It has, in any case, always been rare in New York for any candidate to seek, let alone secure, nominations for more than one of the major parties (i.e. Democrats and Republicans). ${ }^{2}$

Initially, multiple filing in California followed this same general pattern, with some Republicans and Democrats seeking to bolster their appeal by adding Progressive, Socialist, or Prohibition nominations to their principal party designation. After all of these minor parties receded to the fringe in the 1920s, multi-filing took a new shape: "double-filing" in the two major-party primaries became the modal practice for incumbents and an occasional tactic for challengers and open-seat contestants. The direct impact was that, even though the primaries were closed, in many seats, registered Democrats and Republicans were able to vote for candidates from their own party or for can-

\footnotetext{
${ }^{1}$ An example of the minor parties being decisive is New York's 6th district in 1980. John LeBoutillier received 71,838 votes as the Republican candidate, while Lester Wolff won 74,319 votes as the Democrat. It was LeBoutillier who went to Washington, though, since he also won 11,299 votes as the Conservative candidate, while Wolff won only 5,890 Liberal votes. A more typical result is the 9th in 1984: Tom Manton won the seat with 71,420 votes as a Democrat over an opponent who combined 54,089 Republican, 7,458 Conservative, and 2,363 Right-to-Life votes.

2 In modern elections, this is possible only if the candidate wins one nomination as a write-in. The only U.S. Representative from New York to hold Republican and Democratic nominations in a general in the 1990s was Charlie Rangel in 1990, running in what was then the 16th (Harlem), a very-safe Democratic seat routinely abandoned by the Republican party.
} 
didates from the other major party who had cross-filed. This is, more or less, what opening the primary under the blanket system achieves as well. The cross-filing period, then, is a natural era to examine for insight and clues into how the new blanket primary era will unfold.

This chapter explores the comparison between these two distinct but obviously related electoral systems. We first provide a brief background discussion of primary elections in American political history and the original passage of a primary election law in California. No sooner had California inaugurated a system of party-controlled nominations than candidates and voters invented a means of bypassing party control via cross-filing. We discuss the significance of this practice, and present evidence on its incidence, and on how it affected voting. Our goal, at this stage, is to explore the similarities and dissimilarities between multi-filing primaries and blanket primaries, in an effort to extract the history most relevant to those whose interest lies in how the blanket can be expected to settle now that it has been draped over the state. Finally, we review the multiple stages by which the blanket primary became law and then, immediately, was modified, yet again uncovering a tale of partisan elites versus the party-wary masses.

\section{ORIGINS AND IM PLICATIONS OF PRIMARY ELECTIONS}

The primary election is an early twentieth century "progressive" invention. Primaries were adopted in many American states as a substitute for conventions, in an effort to pry power away from strong party bosses and machines and relocate it with candidates and the mass electorate. In California, as in some other states, much of the controversy surrounding the adoption of direct primaries concerned provisions for electing U.S. Senators. The first attempt to establish mandatory primaries in California occurred in 1897. That act fell to court challenges without actually being implemented, as did similar legislation passed in 1899 and 1900 (Young 1943, 117-118). Since all of these legislative efforts preceded the advent of popular election of U.S. Senators (i.e. the Seventeenth Amendment), they were regarded as being partly-or even principally-back-door means of transferring the power to elect Senators from state legislators to the general public, and were applauded or abhorred accordingly. Oregon had set an early example of how a direct primary could achieve this exact purpose of tying the state legislature's hands, and so there was growing popular support in California for some form of primary. By 1908, a constitutionally satisfactory approach was found: A.C.A. 3, which directed the legislature to "enact laws providing for the direct nomination of 
candidates for public office," thereby amending section $2 \frac{1}{2}$ of Article II of the Constitution, passed both houses by more than the two-thirds required for constitutional amendments (State of California 1920, 74). At the general election of 1908 , the public approved A.C.A. 3 by $76.6 \%$ to $23.4 \%$, with every county favoring the amendment by a lopsided margin (Statement of the Vote... 1908, 14).

The 1909 session of the California legislature then opened with a three month-long battle between a bipartisan reform (pro-primary) coalition and a bipartisan pro-machine (anti-primary) coalition. Some type of primary seemed inevitable, but opponents strove to craft either an innocuous law that would change nothing or an unconstitutional one that would be struck down by courts before it could take effect. Following a tortuous chronology of amendments and reconsiderations, several near-tie roll calls, a week of deadlock in the Senate (maintained by hourly postponements!), plus various reversals of position by individual legislators, the law that was ultimately passed did not allow for de facto election of U.S. Senators, but did establish closed, partisan primaries for other offices (see Hichborn 1909, 68-120 for a detailed, plainly-not-disinterested account of the bill's passage).

Franklin Hichborn devoted decades to covering city politics in San Francisco and the dominance of California state politics by the Southern-Pacific Railroad and its allies. ${ }^{3}$ For several sessions in the 1910s and 1920s, one can compute A.D.A.-style "progressivism" scores for all members of both houses of the California legislature using the key votes and pro-reform positions identified by Hichborn on the basis of his intensive legislature watching. ${ }^{4}$ The 27 pro-primary Senators (20 Republicans, 7 Democrats) had an average progressivism score of 72 , while the 13 foes (11 Republicans, 2 Democrats) aver-

\footnotetext{
${ }^{3}$ See Hichborn (1915) on city politics in San Francisco, and his five guides to particular legislative sessions on state politics. His papers are archived in the Haynes Foundation library in Los Angeles, and copies are available at Stanford University. They are a treasure trove for the student of California's political history. To our knowledge, Hichborn was the first observer of legislatures to record roll call votes and then score legislators for their actions. He preceded the A.D.A. by almost 40 years!

${ }^{4} \mathrm{Hichborn}$ selected 16 key votes for the Senate and 11 for the Assembly, and in each case one vote concerned the primary. We omitted the votes on the primary itself when computing the scores. We calculated two versions, one in which abstention was regarded as equivalent to being against reform (score $=100 \times$ pro-reform votes/ all key votes), and one in which it was treated as neutral (score $=100 \times$ pro-reform votes/ (pro-reform votes + anti-reform votes)). The latter values are reported in the text. The corresponding values under the former method are 62 and 25 for the Senate, and 84 and 34 for the Assembly.
} 
aged only 28. In the Assembly, the 36 (11 Democrats, 25 Republicans) in favor of reform on a critical primary vote averaged a score of 88 while the average for the 38 opponents (5 Democrats and 33 Republicans) was 50 points lower, at 38. It seems clear that the partisan primary emerged from a populist movement that spanned the major parties, uniting the members who were most likely to vote against entrenched interests (particularly big business) and to vote for major social reforms and institutional innovations that promoted more transparent government. 5

Since 1910, then, California's state and national elective offices have been filled by elections occurring in two rounds. In the spring or summer, the major (and minor) parties hold primary elections to select nominees for the state's elective offices. Primary winners then compete in N ovember for elevation to the office in question. While the advent of the primary weakened central party organizations, by admitting the mass electorate into the nomination process, the closed nature of the primary strengthened parties in the electorate. That is, only those registered with a given party were permitted to vote in that party's primary, and so party membership (by way of registration) became important. Moreover, part of the compromise by which the primary was passed was inclusion of rules intended to ensure that candidates be authentic partisans. A candidate was required "to make affidavit "that he affiliated with [the party whose nomination he sought] at the last preceding general election, and either that he did not vote thereat, or voted for a majority of the candidates of said party at said preceding general election, and intends to so vote at the ensuing election'" (California Statutes 1909, 694, quoted in Hichborn 1909, 72).

The closedness of the primary and the candidates' affiliation-pledge requirement were plainly at odds with the nonpartisan, or perhaps more accurately, anti-party, spirit that was sweeping the state at that time. Enough Progressives were carried into office on Hiram Johnson's coattails in 1910 that the legislature was able, after the passage of only two election campaigns, to do away with the candidate pledge requirements, and to make explicit the right of candidates to seek multiple party nominations without regard to their own registration or voting history. "Cross filing," wherein candidates ran in two (or more) primaries quickly became normal, first for state races, then for con-

\footnotetext{
5 In the evenly divided 1909 session, the primary was a lone victory for anti-machine forces, as bills introducing the initiative, recall, a simplified secret ballot, and a non-partisan judiciary all failed.
} 
gressional races. Indeed, the first election in which candidates could file for multiple party nominations was 1914, and nearly half the members of the 1915 Assembly won their seats holding the nominations of more than one party! ${ }^{6}$

By 1915, the state had made local elective offices nonpartisan, and Governor Johnson was urging the legislature to follow suit by making its own elections nonpartisan as well (see Hichborn 1922, 221-222 for the text of Johnson's biennial message to the legislature in 1915). In 1910, Johnson had won a fiveway Republican primary before besting Democratic, Socialist, and Prohibition candidates in the general. In 1914, however, he opted to run only as a Progressive, eschewing major-party designation despite the fact that Progressives accounted for less than $20 \%$ of all registered voters. His personal popularity was so great that he nearly won a majority of the vote all the same. In yet another five-way race, he took $49.7 \%$ of the vote, with the Republican and Democrat finishing $20 \%$ and $37 \%$ behind, respectively. Johnson was much less successful in his efforts to persuade the legislature to rid itself of parties, perhaps in part because of a mistake in tactics.

The primary remained inextricably linked to nonpartisanship, and both were subjected to popular approval in a 1915 special election, wherein the key item was a measure that would make the primary, and hence the operation of the legislature, non-partisan. By Hichborn's account, this election "more than anything el se seemed in its results to voice a protest at calling special elections for the consideration of such matters" (1922, 222). Turnout was low and all eleven submitted measures were defeated, even the ones against which no opposition campaign at all had been waged. As a consequence, the legislature did not establish a nonpartisan primary to do away with its partisan organization.

In the 1917 session, moreover, the legislature amended the Direct Primary Law in the opposite direction. On the justification that the special election had reveal ed little support for ridding the state houses of parties, state legislators added a new requirement that a candidate could not win the nomination for a party other than the one for which he was registered without also

${ }^{6}$ Joining 24 Republicans, 10 Democrats, 7 Progressives, and 2 Socialists were 10 members with both Republican and Progressive nominations ("Republican-Progressives"), 8 RepublicanDemocrats, 7 Democratic-Progressives, 6 Republican-Democratic-Progressives, 1 RepublicanDemocratic-Prohibitionist, 1 Republican-Progressive-Prohibitionist, 1 Democratic-ProgressiveProhibitionist, 1 Republican-Democratic-Progressive-Prohibitionist, and even 1 member nominated by all five parties, a Republican-Democratic-Progressive-Prohibitionist-Social ist (Statement of the $V$ ote at the $G$ eneral Election of N ovember 3, 1914, 4-5). 
winning his own party's nomination. In the August 1918 primaries, this precise scenario played out at the top of the ticket, as James Rolph, Jr., a registered Republican, took $45.6 \%$ of the Democratic vote, to $36.9 \%$ and $17.6 \%$ for two rivals, but finished second in the Republican race, with $39.2 \%$ against 45.1\% (the balance being distributed amongst four others). Rolph was thus defeated as the Republican nominee for Governor and disqualified as the Democratic nominee, and so no one was permitted to run under the Democrat banner in the general. Before the 1920 el ections, still further amendments empowered county party committees to fill vacancies created in this manner by appointment, just as they could fill vacancies created by death or by an absence of any filers for the primary. So it was that, under special circumstances, party organizations again took control of nominations, in stark violation of the spirit of the primary. ${ }^{7}$

Over the next decades, scarcely a legislative session passed without some proposal to amend the direct primary. Efforts to extend the anti-party strains by making the primaries (and, hence, the legislature) non-partisan were about as common as counter proposals to forbid cross-filing altogether and revert to basic closed primaries in which registered Republicans select Republican nominees, registered Democrats select Democratic nominees, and never the twain do meet.

Neither side triumphed in extending or defeating cross-filing principles until 1952, when two propositions on the general election ballot competed to change the status quo. Proposition 13, an initiative, would have prohibited cross-filing by specifying that "no person shall be a candidate or nominee of a political party for any office unless he has been registered as affiliated with such party for at least three months prior to filing nomination papers." The campaign for signatures to qualify this initiative was, in a strictly literal sense, bipartisan, as the League of Women Voters joined a former Republican state senator and a Democratic oil millionaire in its support (Davies 1951). The support for Proposition 13, however, was much more Democratic than Republican. Not too surprisingly, then, the Republican-controlled legislature drafted an alternative to Proposition 13. Proposition 7 merely required that

\footnotetext{
7 It might seem that this power to appoint nominees was unlikely to have mattered, given that committees could act only if all the candidates registered with their own party had lost to outsiders, an outcome that would seem to signal that the seat was a hopeless cause for the party in question. In general, though, primary races with many candidates and/ or many cross-filers seem not to have been very good predictors of subsequent general election results, and some committee-appointed stand-ins did actually win general elections.
} 
"the ballot shall show political party affiliation of each candidate for partisan office, as shown by candidate's registration affidavit." Proposition 7 passed easily, $72.8 \%$ to $27.2 \%$, with majority support in every county (most counties closely matching the statewide breakdown). Proposition 13 fared less well: it barely failed to achieve majority support with $49.96 \%$ approval statewide (majorities approved in only 19 of 58 counties). Fittingly, where Proposition 7 did well, Proposition 13 did poorly (compared to its statewide performance), and vice versa: the correlation between county percentage approval rates for the two measures is -0.42 . By contrast, the correlation between the Democratic registration percentages and Proposition 13 was +0.21 , reinforcing the suspicion that opinions on the primary were becoming bound up in normal party politics, notwithstanding the fact that some Republicans had taken part in the campaign for Proposition 13.

The other shoe dropped in A pril of 1959. The 1958 elections had delivered the first unified Democratic control of California of the twentieth century, and Governor Pat Brown and the legislature wasted little time in abolishing cross-filing. Media coverage of the bill at the time emphasized that cross-filing was widely thought to favor Republicans. The N ew Y ork Times opined, "California's Republicans, outnumbered [in registration] for the last twenty-seven years, capitalized on cross-filing to maintain a half century's domination of state politics" (Hill 1959a). Closer to the action, the Los A ngeles Times's report on passage of the repeal by the State Senate emphasized that, "abolition of cross-filing has been a Democratic Party objective for years" (no author, 1959). The roll calls reflected that same partisan story. The Assembly passed A.B. 118 on February 24, 1959, with 45 Democrats and 4 Republicans voting in favor against 1 Democrat and 28 Republicans (1 Democrat and 1 Republican abstained). In the Senate, the bill passed 22-15, 21 Democrats and 1 Republican defeating 4 Democrats and 11 Republicans (2 Democrats and 1 Republican abstained). ${ }^{8}$

The interpretation that the Democrats of 1959 were finally in a position to close a pro-Republican loophole is complicated just slightly by the fact that some prominent Republicans expressed support for the change in primary law, and some Democrats lamented the end of the cross-filing era. Only one

\footnotetext{
8 Voting against cross-filing in the Senate were 7 of 10 Democrats who had won Republican nominations in the 1958 primaries, and 1 of 4 Republicans who had won Democratic nominations. In the Assembly, 12 of the 13 Democrats who had also carried the Republican nomination in 1958 voted to abolish cross-filing, while both of the Republicans who had won the Democratic nomination voted against abolition.
} 
member of California's congressional delegation spoke out against the repeal, Senator Thomas Kuchel (R), who struck a very Progressive tone: "The people of California are not extremely partisan-they want dean, strong and honest government. In my judgment, cross-filing has helped them get it" (Shannon 1959). Moreover, the contention that cross-filing was somehow inevitably favorable to Republicans was rarely backed with any explicit logic. From the advent of party labels in 1954 to 1958, there were 11 instances of Democrats winning the Republican nomination for U.S. House seats, against 0 Republican victories in Democratic primaries. It seems plausible that cross-filing might have favored incumbents, insofar as simple name recognition ensured them an advantage over challengers amongst the less intensely partisan registered voters. If this were so, it would mean that the ability to cross-file worked to the advantage of the Republicans when they were the stronger state party, but started to help Democrats, on balance, after the state began to lean their way in the late 1930s. We shall return to this question in the next section.

Figure 2.1 shows three indirect indicators of the prevalence of multiple filing for U.S. House and California Senate contests in the 23 elections in which it was permitted (1914-1958). 9 Before and after that period, generalelection winners almost invariably held only one party's nomination, the exceptions being candidates who won extra nominations by write-in campaigns. By contrast, the dashed line shows that, on average, winners held about 1.5 nominations in this era, and in 1918 actually averaged more than 2 party nominations each. The average number of candidates in competition for California's U.S. House seats was high at the outset of the era, when the Progressive, Socialist, and Prohibition parties were still active. However, it quickly fell, as fewer and fewer individuals secured more and more nominations. Accordingly, the average value for a size-weighted count of candidates (the socalled "effective number") fell nearly to one, indicating that most districts were dominated by one individual, standing as the candidate for more than one party. ${ }^{10} \mathrm{~N}$ ot until the late 1950 s did California's U.S. House elections take

\footnotetext{
9 The data analyzed in this chapter were obtained from the relevant official primary and general Statement of V ote reports released by the California Secretary of State. The electronic dataset was created from these sources by the authors.

10 The "effective" number of candidates is an index that weights the actual number of candidates according to their vote shares, so that strong candidates count far more than weak ones. We used the most common such measure in the voting literature, the Laakso-Taagepera index (1979), computed district by district. The values in Figure 1 are averages, computed as: $\mathrm{N}_{\mathrm{e}}=$ $\mathrm{I} / \mathrm{n} \Sigma_{\mathrm{i}}\left[\left(\Sigma_{\mathrm{j}} \mathrm{V}_{\mathrm{ij}}\right)^{2 /}\left(\Sigma_{\mathrm{j}} \mathrm{V}_{\mathrm{ij}}^{-}\right)\right]$, where $\mathrm{V}_{\mathrm{ij}}$ is the number of votes won by candidate $\mathrm{j}$ in district $\mathrm{i}$, and
} 
the familiar modern A merican shape of competition between two candidates, each of whom represents one of the two major parties.

The significance of the foregoing is that primary elections in which a voter may cross over to support candidates from a party other than his own are not new to California. Whereas the modern practice has been to "open" primaries by permitting some party-crossing behavior on the part of voters,

there are a total of $\mathrm{n}$ districts in the state (or, as applicable, $\mathrm{n}$ districts in which there is some competition). 
Figure 2. 1

A. US House Seats

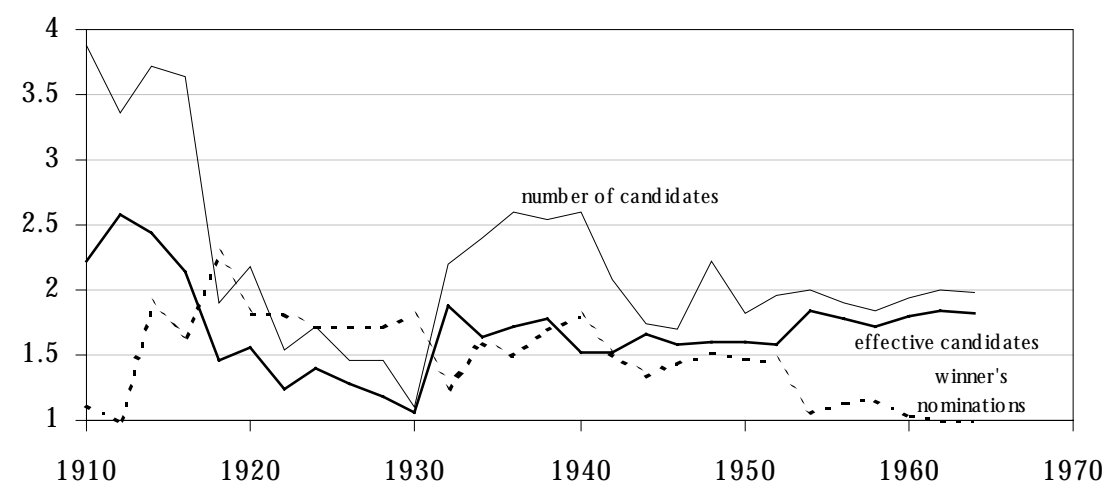

N seats: 11 (1914-30); 20 (1932-40); 23 (1942-50); 30 (1952-60); 38 (1962-64)

B. California Senate Seats

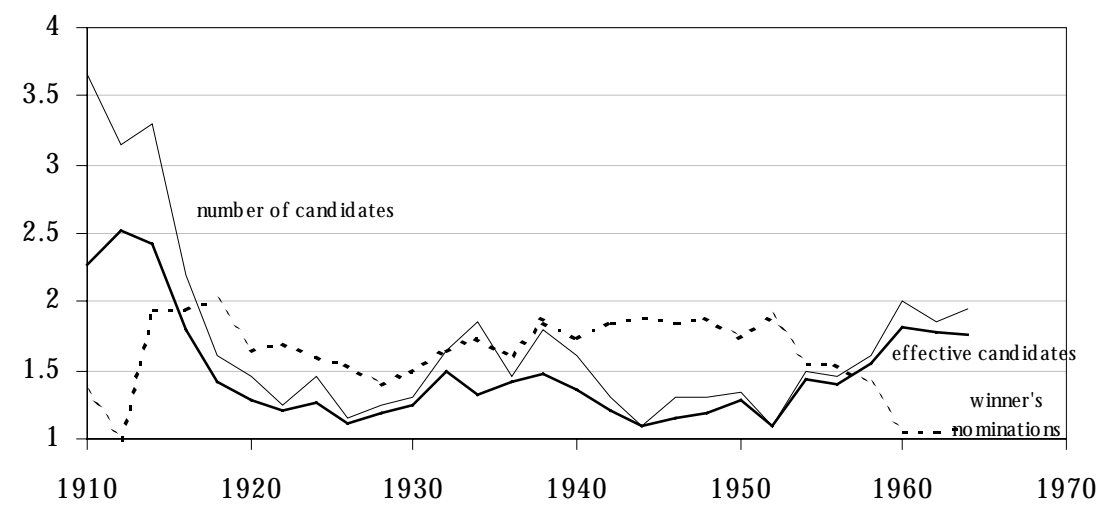

$N$ seats: 20 per election, 40 total 
in California's past, parties' influence was bypassed on the supply side, by allowing candidates to straddle party organizations for electoral purposes.11 We turn now to an analysis of the actual voting patterns under these rules.

\section{WhO WERE THE X-FILERS? Contexts, CANDidates, And Cross-over voting}

The next task in assessing the similarities between cross-filing and the blanket primary is to consider the subtleties of multiple filing and the various possible incentives it created for cross-over voting. Given the chronology of alterations and amendments described in the previous section, there have now been 7 discernible regimes in California's historical experience with primary elections, 4 of which fall in the multi-filing period. Table 2.1 summarizes the key differences with respect to cross-over voting and party nominations at the general election.

Of all the primary elections in the cross-filing era, probably those of 1914 and 1916 most resemble the blanket primary in strictly procedural terms. In both time periods, the top finisher from each party moves on to the general, regardless of relative totals. Under the blanket, voters can support any candidates who file for office, without regard to the voters' or candidates' parties of registration. In the 1914 and 1916 elections, voters could support any candidates who filed in their parties' primaries or even candidates who did not do so if they (the voters) took the extraordinary step of casting write-in votes. Since write-in votes are important only in races which are already aberrant, typically because the seat has been deserted by one major party, it is safe to say that the blanket system is a slightly friendlier environment for cross-over voting. Or, at least, voters' options are less constrained by choices made by candidates. The primaries of 1920-1952 were, in turn, less favorable to crossover voting than their predecessors of 1914 and 1916 because of the requirement that a candidate win his own party's nomination in order also to win another party's nomination. With this procedural change, objective strategic conditions for cross-over voting had changed. Some voters inclined to support an outsider in their own primary may have hesitated to do so for fear

\footnotetext{
${ }^{11}$ Candidates el ected with both Democratic and Republican nominations were not, of course, in any legislative sense representatives of both parties. Richard $\mathrm{Nixon}$ and Cecil Young were both elected with both major party nominations in 1948, but there was no doubt that the former was a partisan Republican and the latter a partisan Democrat once they arrived in D.C. to sit in the 81st Congress.
} 


\section{Table 2.1: Primary-Election Regimes In California's H istory}

\begin{tabular}{|c|c|c|c|}
\hline $\begin{array}{l}\text { Election } \\
\text { Years }\end{array}$ & Primary Type & Crossover Voting? & $\begin{array}{l}\text { Multiply Nominated Candi- } \\
\text { dates? }\end{array}$ \\
\hline 1910-1912 & closed & by write-in vote only & $\begin{array}{l}\text { only in districts in which } \\
\text { one party is very weak }\end{array}$ \\
\hline 1914-1916 & closed with cross-filing & $\begin{array}{l}\text { yes, provided candidates } \\
\text { cross-file (or by write-in) }\end{array}$ & yes \\
\hline 1918 & $\begin{array}{l}\text { as in 1916, plus win-own- } \\
\text { party requirement }\end{array}$ & $\begin{array}{l}\text { yes, provided candidates } \\
\text { cross-file (or by write-in) }\end{array}$ & $\begin{array}{l}\text { only for candidates who win } \\
\text { nomination of party with } \\
\text { which they register }\end{array}$ \\
\hline 1920-1952 & $\begin{array}{l}\text { as in 1918, plus party com- } \\
\text { mittee substitutes }\end{array}$ & $\begin{array}{l}\text { yes, provided candidates } \\
\text { cross-file (or by write-in) }\end{array}$ & $\begin{array}{l}\text { only for candidates who win } \\
\text { nomination of party with } \\
\text { which they register }\end{array}$ \\
\hline 1954-1958 & $\begin{array}{l}\text { as in } 1952, \text { plus candidates' } \\
\text { parties identified on ballots }\end{array}$ & $\begin{array}{l}\text { yes, provided candidates } \\
\text { cross-file (or by write-in) }\end{array}$ & $\begin{array}{l}\text { only for candidates who win } \\
\text { nomination of party with } \\
\text { which they register }\end{array}$ \\
\hline 1960-1996 & closed & by write-in vote only & $\begin{array}{l}\text { only in districts in which one } \\
\text { party is very weak }\end{array}$ \\
\hline 1998- & fully open "blanket" & $\begin{array}{l}\text { yes (but not directly } \\
\text { observable) }\end{array}$ & $\begin{array}{l}\text { only in districts in which one } \\
\text { party is very weak }\end{array}$ \\
\hline
\end{tabular}

that the vote would be wasted if the candidate did not win his own primary.

The change in 1918 also opened up the possibility for "spoilers," candidates who could knock others out of the general election by receiving the most votes in a given primary, but not advance themselves because they did not win their own primary. Because of domino effects, spoiling could be hard to anticipate. Consider the primary in the 36th Senate district in 1922 . In that election, Republican candidate A.B. Johnson received 7,571 votes in the Republican primary. Republican F.D. Mather won 6,961 Republican votes, 531 Prohibition votes, and 14 Socialist (write-in) votes. Prohibition candidate C.R. Burger received 1,809 Democratic votes and 414 Prohibition votes. Thus, Johnson defeated Mather for the Republican nomination, and both the Prohibition and Democratic nominations were won by candidates disqualified for not having won their own parties' races. Had just 60 Prohibition voters switched from Mather to Burger, the general election would have pitted a Re- 
publican against a Prohibition-Democrat, rather than having a Republican walt to victory uncontested.

There are, in short, both institutional and non-institutional distinctions to be drawn between different types of primary system and their receptivity to cross-over voting. In some cases, because there were no own-party candidates running in a given race, voters could choose only between abstaining and casting a cross-over vote. This is particularly common, of course, in eras and/ or districts in which one party was especially weak. Another relatively common kind of race pits one Democrat against one Republican. Under the blanket, both candidates are assured of advancing, and the primary's main function is to provide a preview of how the general might unfold, by giving a preliminary reading of the candidates' relative appeals. In the cross-filing years, by contrast, these races could pre-determine the general result, since a candidate who won both nominations was guaranteed to face no major-party opponent in the general. So, in symmetric races that lack real intra-party competition, the stakes were somewhat higher under cross-filing than they are under the blanket, though that does not necessarily mean that cross-over voting should have been more or less likely, on average.

Figure 2.2 disregards all of these concerns about context to show how much cross-over voting occurred in two venues in every election from 1910 to 1964. Panel A depicts U.S. House races and panel B describes the California Senate. The dashed lines are party-specific: they show what proportion of all the votes cast in the Democratic primary went to candidates who were registered Republicans (and who were running in the Republican primary simultaneously) and what proportion of all votes cast in the Republican primary were won by registered Democrats (who were also, of course, competing in the Democratic primary). The solid line marked "Total" is the proportion of all primary votes that were cast for other-party candidates. It includes Republican and Democratic cross-over votes as well as votes cast for Progressives, Socialists, or Prohibitionists running in the Republican or Democratic primaries. 12

The two panels tell similar stories. In 1910 and 1912, before cross-filing was permitted, there was a tiny amount of cross-over voting occurring by way

\footnotetext{
12 The figure slightly under-counts cross-over voting because, as a consequence of the way we collected the data, we do not include in our cross-over total votes won by other-party candidates in minor-party primaries (e.g. Prohibition primary votes cast for a registered Socialist or registered Democrat who cross-filed).
} 
of write-in votes. In a few cases (e.g. the 3rd U.S. House district in 1910), a 
Figure 2.2
A . US House Primaries

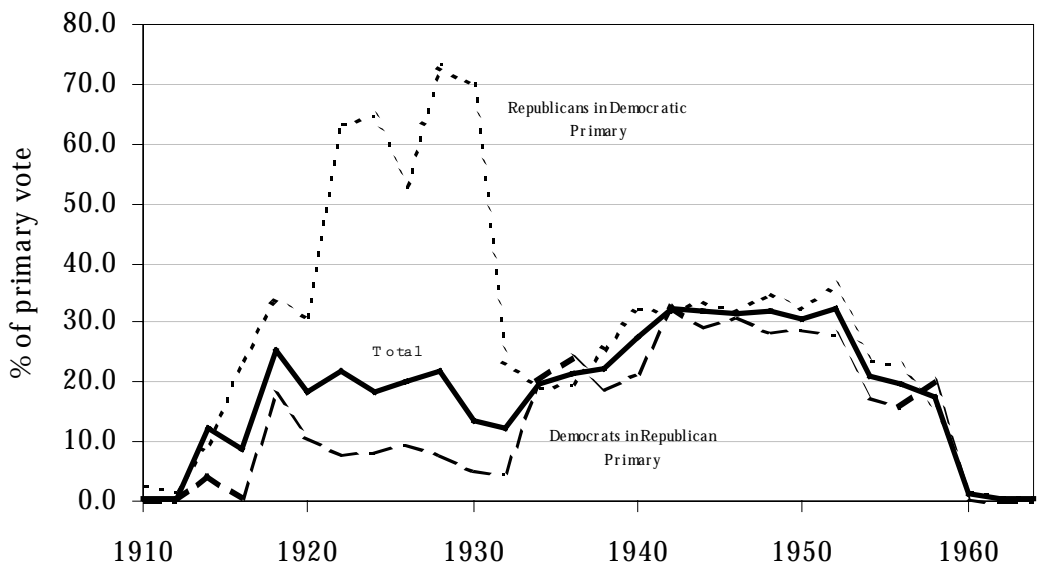

B. California Senate Primaries

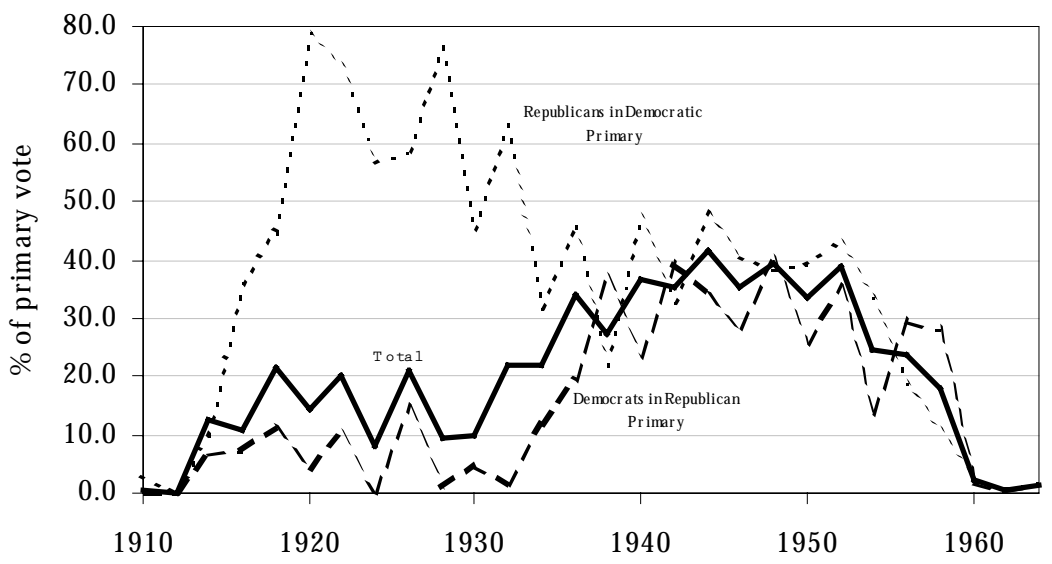


candidate won Democratic and Republican nominations simply because no opponent from the other major party ran, and so a campaign to generate a small number of write-in votes was sufficient for victory. When multiplefiling became legal in 1914, cross-over voting increased markedly. In 1914 and 1916 , cross-over voting accounted for about $10 \%$ of the primary vote. From 1918 to the mid-1930s, it was more common still, constituting about $20 \%$ of the primary vote. This was an era of Republican strength, and cross-over voting was, accordingly, very asymmetric: Republican candidates dominated the Democratic primaries, while only a handful of Democrats captured any votes on the Republican side. With the New Deal realignment, the picture changed again. From the mid-1930s to the mid-1950s, cross-over voting accounted for about $30 \%$ of the U.S. House vote and about $40 \%$ of the State Senate vote, and it was nearly evenly balanced between Democrats drawing support from $\mathrm{Re}$ publican voters and Republicans drawing support from Democratic voters (the minor parties having all but vanished). Finally, the explicit labeling of candidates' own registration status on primary ballots in 1954, 1956, and 1958 seems to have been consequential: cross-over rates fell back to the $20 \%$ range over these elections. Once multi-filing was abolished, cross-over voting dropped to negligible rates as it was, again, possible only through writein campaigns. In the early 1960s, these were symbolic (and futile) protests against the abolition of multiple filing. Thereafter, they disappeared altogether.

One other point about Figure 2.2 is that it is especially sensitive to malapportionment. Because U.S. House districts varied considerably in population over this era, some districts are more influential than others in computations like these, which simply aggregate over the entire electorate. This is truer still for the State Senate, which, from 1932-1964, was exceptionally malapportioned by design. No county, however populous, was allotted more than one Senator, and the 40 Senate seats were distributed to the 58 counties by combining the smallest few counties into duos or trios (see Brady and Gaines 1995 on the origins and implications of this system). Since Figure 2.2 counts all voters equally, it is appropriate for analyzing mass behavior, taking institutions as prior and fixed. The 2.8 million voters in Los Angeles county (Senate district 38) in 1958 count about 350 times as much as the 8,000 voters in Alpine, Inyo, and Mono counties (district 28) in an analysis of voters, not districts. If, instead, one is interested in the joint effects of institutions and be havior, one can treat districts as units and average district cross-over voting rates without regard to how many voters reside in each one. This approach 
treats districts 38 and 28 as observations of equal significance, weighting them equally.

Figure 2.3 takes the latter approach and averages rates across districts, without any weighting for district population. We also return to the problem of distinguishing different reasons to cross over in primary voting by plotting time series for four categories of cross-over votes. Some cross-over voting occurred for the simplest of reasons: no candidate registered with the relevant party filed, and so voters who went to the polls and preferred not to abstain from voting in the given race could only back candidates from other parties. We use the label "no option" for all such cross-over voting. In all remaining cases, primary voters did have a choice between candidates registered with their own party (who might or might not have been running in other primaries) and cross-filers who were registered with another party and running in at least one other primary. We distinguish between cross-over votes cast for an incumbent (e.g. Democratic primary voters supporting a Republican incumbent), against an incumbent (e.g. Democratic primary voters supporting a Republican non-incumbent rather than a Democratic incumbent), and in races in which no incumbent was running.

The figures reveal more contrast between the two chambers than did Figure 2.2. Panel 2.3A, describing the U.S. House, is broadly reminiscent of panel 2.2A. From 1914 to 1940 , districts saw, on average, 5-10\% of the primary vote crossing over because of lack of choice. In two presidential election years (1924 and 1928), this rate was much higher, as 15-20\% of all votes in the average district were forced cross-overs. After 1940, there was very little voting of this kind. Open-seat and anti-incumbent cross-over voting, by contrast, were unimportant until the 1940s. Then, from 1940 to 1950, the district averages for each were about $5 \%$ to $10 \%$. These fell sharply in the 1950 s, even before the final abolition of cross-filing in 1960. The dominant form of cross-over voting, then, was pro-incumbent. From 1914 to 1932, the average rate of cross-over voting in favor of incumbents was 5-10\%. From 1932 to 1948, this share rose steadily, peaking at over $20 \%$. Even after the candidate labeling rules of 1954 , about $15 \%$ of the primary vote was cast against party registration, to incumbents, before the changes of 1960 ended the practice.

No patterns in the State Senate are quite as clear. In most years, the districts averaged higher rates of all varieties of cross-over voting than did their U.S. H ouse counterparts. In stark contrast to the patterns found in U.S. H ouse elections, forced cross-over voting was somewhat more common late in the series than early. On the other hand, as in theU.S. House case, there were de- 
Figure 2.3

A. A verage Rates for Types of Cross-O ver V ote, U.S. H ouse

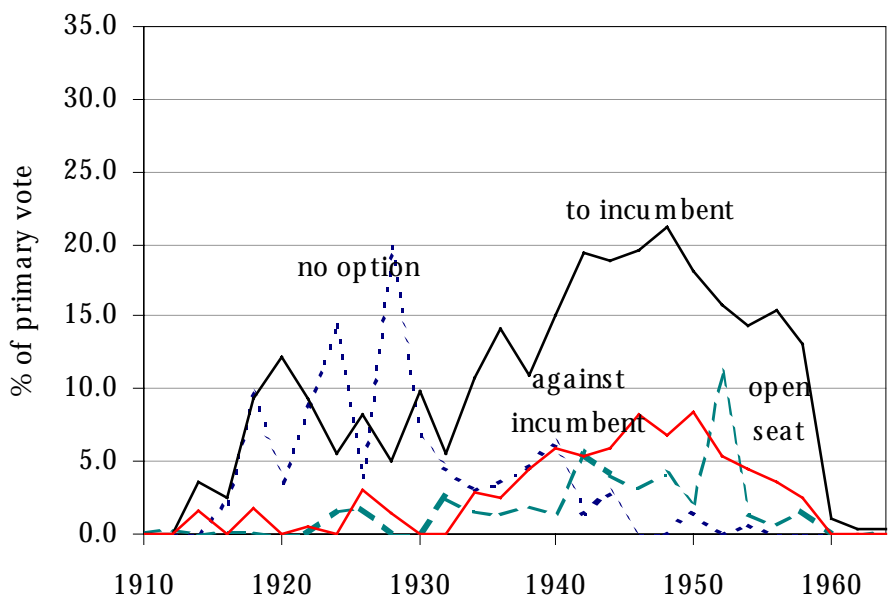

B. A verage Rates for Types of C ross- $O$ ver $V$ ote, California Senate

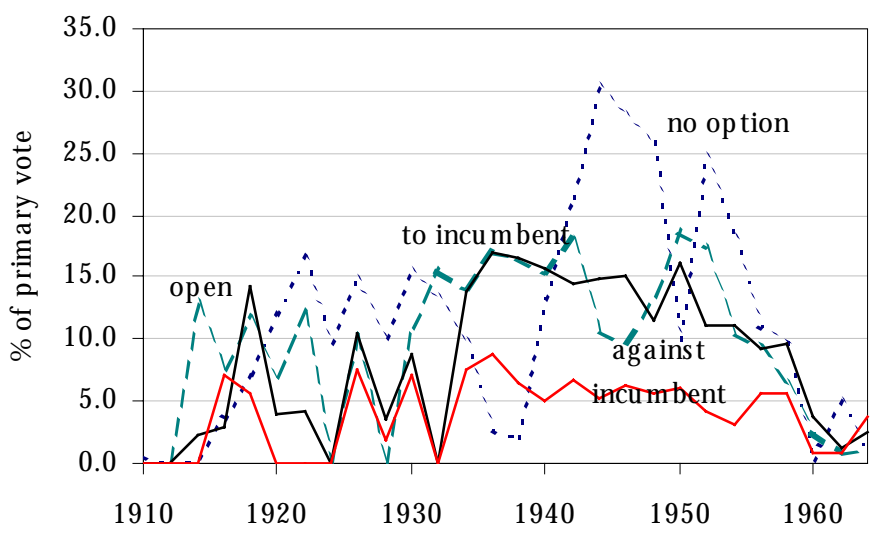


clines in the average district rates of all kinds of cross-over voting after the 1954 party-label rules came into play.

The implication of this drop in cross-over voting after candidates' party registrations were printed on the ballots is that some voters must have been crossing over unintentionally, not realizing that the candidates they were supporting were in fact registered members of another party. A plausible conjecture about such voting is that much of it originated in incumbency status. Indeed, it is a staple of research on the incumbency advantage in congressional general elections that incumbents are able disproportionately to attract support from voters who do not identify with the incumbent's party. Case studies bolster this impression, that cross-over voting extended the incumbent's edge in reaching across parties back to the primary stage. For instance, years after he lost the 1948 Democratic primary in California's 12th district to Richard Nixon, Democrat Stephen Zetterberg cited cross-filing as the culprit, complaining that "Nixon, concealing his Republican Party affiliation, used to advantage that his name came first on the ball ot due to his incumbency and that his campaign committee promoted the 'Dear Fellow Democrat' advertising format, enticing enough unsophisticated Democratic voters, who did not understand the crossfiling procedure, into casting their ballots for him." Indeed, it appears that crafting a separate appeal aimed directly at Democrats was "the media strategy in the local newspapers" for the Nixon campaign (Gellman 1999, 179-180).

Zetterberg's description conflates a few different points. Incumbents may have profited from the simple advantage of appearing first on ballots, but they undoubtedly had a general edge in name recognition to boot. The post1952 drop-off in pro-incumbent crossover voting that occurred in both the U.S. House and California Senate races is indirect evidence that "unsophisticated" voters may well have been mistaking the better-known candidate for their own partisan brethren. On the other hand, pro-incumbent cross-over voting continued to comprise about $10 \%$ of the vote in districts after candidates' parties were explicitly noted on the ballot, so some of the cross-party appeal seems to have been genuine. Nixon's strategy was not so much to "conceal" his identity as a Republican, as to advertise the support of prominent Democrats for his candidacy. And, of course, Nixon had earned his incumbency status by beating then-incumbent Democrat Jerry Voorhis in 1946, not in the general election only, but in the Republican primary as well. In short, the ability to cross-file and cultivate cross-over support rendered primary elections more like general elections, where incumbents could success- 
fully transcend partisan ties and were vulnerable only to concerted efforts by high-quality opponents.

This general climate is precisely what the blanket system is supposed to deliver as well. Candidates able to craft appeals to all voters, not only those who share their party registration, can broaden their bases, encourage crossparty coalitions of moderates, take advantage of non-partisan appeal and superior recognition, and so on. There is little reason to believe that Nixon was alone in taking advantage of the institutional environment by developing a two-track strategy to win Democratic and Republican votes.

Table 2.2 presents one more analysis of cross-over voting rates and the effects of institutional context (the different combinations of rules in place) and political context (incumbency status). Our observations are U.S. House and State Senate districts, and we regress the proportion of the primary vote that consists of cross-over votes on indicator variables for periods, an indicator for whether there was cross-filing incumbent in the race, another indicator for races having incumbents who did not cross-file, a simple count of how many non-incumbents had cross-filed, and a variable identifying a district as competitive.13 Finally, because the districts vary widely in population, we added the natural logarithm of the total number of primary votes cast as a further control variable.

Models (1) and (3) include, respectively, all districts and all U.S. House districts. Models (2) and (4) investigate the robustness of the findings by omitting all cases in which there was no cross-over vote at all. The results reemphasize the points illustrated in Figure 2.3. First, the presence of a crossfiling incumbent greatly increased the amount of cross-over voting in all models, by a substantial $15-25 \%$. In models (1) and (2), races in which an incumbent ran but did not cross-file saw 3-8\% declines in cross-over voting, presumably because the incumbent drew support in his or her own primary that might otherwise have gone to cross-filers from other parties. Since the coefficient on this variable was not significant in models (3) and (4), it appears that this dampening effect was stronger in the California Senate than in the

\footnotetext{
13 This competitive-district dummy variable was developed by computing normal votes for districts using general election returns and then adjusting these according to whether or not there was any partisan turnover observed in the relevant reapportionment period. We used a simple dichotomy: safe (Democratic or Republican) seat (i.e. high or low normal Democratic vote, little turnover) versus competitive (middle-sized normal vote plus some turnover.) A paucity of contested general elections made the estimation difficult for the state Senate, so we computed this measure for the U.S. House districts only.
} 
U.S. House, and/ or that it was mostly in competitive seats that incumbents 
Table 2.2: Cross-Over V ote Proportions, California Senate and US House, 1910-1964

\begin{tabular}{|c|c|c|c|c|}
\hline & & $\begin{array}{r}\text { Cross-over } \\
\text { vote }>0\end{array}$ & $\begin{array}{r}\text { U.S. House } \\
\text { only }\end{array}$ & $\begin{array}{r}\text { U.S. House, } \\
\text { cross-over } \\
\text { vote }>0\end{array}$ \\
\hline & (1) & (2) & (3) & (4) \\
\hline Intercept & $\begin{array}{l}0.32^{*} \\
(0.04)\end{array}$ & $\begin{array}{l}0.40^{*} \\
(0.05)\end{array}$ & $\begin{array}{l}-0.16 \\
(0.12)\end{array}$ & $\begin{array}{r}-0.40^{*} \\
(0.17)\end{array}$ \\
\hline 1914-1916 & $\begin{array}{l}-0.04^{*} \\
(0.02)\end{array}$ & $\begin{array}{r}0.00 \\
(0.03)\end{array}$ & $\begin{array}{l}-0.02 \\
(0.03)\end{array}$ & $\begin{array}{r}0.06 \\
(0.04)\end{array}$ \\
\hline 1918-1952 & $\begin{array}{l}0.16^{*} \\
(0.01)\end{array}$ & $\begin{array}{r}0.25^{*} \\
(0.02)\end{array}$ & $\begin{array}{l}0.14^{*} \\
(0.01)\end{array}$ & $\begin{array}{l}.256^{*} \\
(0.02)\end{array}$ \\
\hline 1954-1958 & $\begin{array}{l}0.10^{*} \\
(0.02)\end{array}$ & $\begin{array}{l}0.19^{*} \\
(0.02)\end{array}$ & $\begin{array}{r}0.05^{*} \\
(0.02)\end{array}$ & $\begin{array}{r}0.15^{*} \\
(0.02)\end{array}$ \\
\hline Cross-filing incumbent & $\begin{array}{l}0.14^{*} \\
(0.01)\end{array}$ & $\begin{array}{l}0.09^{*} \\
(0.01)\end{array}$ & $\begin{array}{l}0.14^{*} \\
(0.01)\end{array}$ & $\begin{array}{l}0.09^{*} \\
(0.02)\end{array}$ \\
\hline Non-cross-filing incumbent & $\begin{array}{l}-0.03^{*} \\
(0.01)\end{array}$ & $\begin{array}{l}-0.08^{*} \\
(0.03)\end{array}$ & $\begin{array}{l}-0.01 \\
(0.02)\end{array}$ & $\begin{array}{l}-0.04 \\
(0.04)\end{array}$ \\
\hline $\begin{array}{l}\text { Number of other cross- } \\
\text { filers }\end{array}$ & $\begin{array}{r}0.03^{*} \\
(0.004)\end{array}$ & $\begin{array}{r}0.01^{*} \\
(0.005)\end{array}$ & $\begin{array}{r}0.03^{*} \\
(0.005)\end{array}$ & $\begin{array}{r}0.01^{*} \\
(0.006)\end{array}$ \\
\hline In (total votes cast) & $\begin{array}{l}-0.03^{*} \\
(0.004)\end{array}$ & $\begin{array}{l}-0.04^{*} \\
(0.005)\end{array}$ & $\begin{array}{r}0.01 \\
(0.01)\end{array}$ & $\begin{array}{r}0.03^{*} \\
(0.02)\end{array}$ \\
\hline Competitive district & & & $\begin{array}{r}0.002 \\
(0.009)\end{array}$ & $\begin{array}{l}0.002 \\
(0.01)\end{array}$ \\
\hline $\mathrm{N}$ & 1119 & 877 & 559 & 425 \\
\hline Adjusted $R^{2}$ & 0.50 & 0.35 & 0.56 & 0.37 \\
\hline
\end{tabular}

$*_{p}<0.05$

ran without cross-filing in the House. The direct effect of the competitivedistrict variable, was, in any case, not significant, so cross-over voting does not seem to have been sensitive to the prospects of a close race ensuing in the general for the U.S. House, ceteris paribus. As expected, the number of crossfiling non-incumbents mattered: the more such candidates, the higher the cross-over vote. Finally, the period indicator variables verify that the 19181952 period saw the highest levels of crossing over, the 1954-58 period saw the second highest levels, and 1914-1916 was, all else equal, barely distinguish- 
second highest levels, and 1914-1916 was, all else equal, barely distinguishable from 1910-1912 and 1960-1964, when cross-over voting happened only by write-in.

We take this finding to signify that voters and candidates require time to learn how institutions shape their incentives. Some cross-filing and, in turn, cross-over voting, quickly followed the introduction of the new primary rules in 1914, but several elections had passed before the phenomenon peaked in importance. Most, but not all, of the party-defying votes were cast for incumbents, suggesting that weakening parties in the primaries assisted those already in power. Differences between the U.S. House and California Senate alert us to the need to qualify this claim. Whether incumbents sought to exploit cross-filing and how voters then responded seems also to be connected to the context of the race in ways we cannot precisely delineate. Finally, the continuation of cross-over voting even after ballots were al tered to al ert voters to candidates' true partisanship implies that some voters were consciously supporting candidates from foreign parties, presumably because the candidates appealed to them in some non-partisan manner.

A few implications for how the blanket primary may develop over the near future follow. First, and most obviously, it is not wise to draw strong conclusions about how the blanket rules will affect candidate and voter be havior after only one election under the new rules. It may take a few elections before any kind of equilibrium is reached. Cross-over voting in a blanket primary is something like cross-over voting in the 1954-58 elections since the candidates' party identities are known. Some of the strategic decisions of the past, though, such as whether or not to cross-file for those who have already decided to file, no longer apply. So voter strategy is slightly less intertwined with candidate strategy under the blanket than it was in the cross-filing pe riod. Probably, all else equal, incumbents will be favored by removal of party-registration walls, as they were in the past. Some of the variation between the U.S. House and California Senate in voting behavior may have followed from other institutional differences, such as the vastly dissimilar methods of apportionment used for each from 1930 to 1964. The fact that Senate districts were, with very few exceptions, not altered over this period, had implications for district competitiveness. Although we have not presented evidence that cross-over voting levels having been responsive to districts' general-election competitiveness, we continue to suspect that the expectation of a competitive race may be an important determinant of how cross-over votes are cast. If so, the effects of the blanket primary rules will be filtered through 
other contextual factors, such as how competitive are the new districts drawn for 2002 and beyond, how campaign finance laws vary across venues, and so on.

\section{Weaving (and UnWeaving) The BLANKet}

As of the spring of 2000, California's blanket primary has had a short but eventful life, which has so far proceeded in six acts: (1) it became law when Proposition 198 was approved in the primary election of March 1996; (2) it survived a court challenge mounted by the major and minor parties in decisions handed down by the US District Court in 1997 and the 9th Circuit Court of Appeals in March of 1999; (3) its application to presidential elections was threatened in July 1998 when Governor Wilson signed S.B. 1505 into law, thereby placing Proposition 3 on the November 1998 ballot; (4) however, it then remained unaltered as Proposition 3 was soundly defeated at the polls; (5) in a further reversal, it was subsequently altered, all the same, in May of 1999 by the passage into law of S.B. 100, a bill making the "openness" of presidential primaries merely cosmetic and requiring a simultaneous closed vote to occur and to be controlling with respect to actual convention delegate selection; and, finally, (6) In April 2000, the US Supreme Court reviewed the Appeals Court decision.

Perhaps surprisingly, the electoral battle over Proposition 198 was not waged in dollars. It was opposed by both major parties, but they allowed themselves to be outspent, possibly having been lulled into inactivity because the measure enjoyed endorsements from only three big-name-value politicians, Republicans Tom Campbell and Becky Morgan and Independent Lucy Killea. State Senator Killea, significantly, was not only a former Democrat, but was al ready associated with quixotic reform efforts because of her prior campaign to promote unicameralism for the state legislature. The reasons underlying the two major-party figures' support for the open primary measure, meanwhile, can be discerned from their intertwined career paths.

Campbell is a moderate who served two terms in the U.S. House before running in the primary for the U.S. Senate seat left open by the retirement of 78-year-old Alan Cranston, in 1992. He lost that race to a more conservative rival, Bruce Herschensohn, who, in turn, lost the general election $43 \%$ to $48 \%$, against then-Representative Barbara Boxer, a very liberal Democrat. Campbell fumed publicly that he would have had more appeal to independents and moderates in the general, and would, therefore, have beaten Boxer. To stay in the public eye, he ran for the State Senate in a special election in 1993, won, and then marked his time until a suitable U.S. House vacancy emerged. 
Which it did one year after the Republicans seized control of the U.S. House in the 1994 elections, as 10-term Democratic incumbent N orman M ineta opted to trade life in the minority for the lucrative world of lobbying. Oddly, the spe cial election to fill his seat quickly came to be viewed as a referendum on Newt Gingrich and the new Republican majority, and so several state Republican organizations fed maverick Campbell seed money which he parlayed into a two-to-one financial edge over his nearest rival, and an easy 59\%-36\% victory. When the 1996 primary rolled around three months later, he had, left over, a state war chest, and the nearly $\$ 100,000$ he contributed to the proProposition 198 fund came from that account. Morgan, meanwhile, was the state Senator whose mid-term retirement had opened the seat into which Campbell had slipped while he waited for his chance to return to Washington. Like Mineta, she left politics for lobbying, in part because Governor Wilson had opted not to appoint her State Superintendent of Schools (Green 1995, 118). She too was dearing out an outdated Senate account when she gave about $\$ 150,000$ to Californians for an Open Primary early in 1996, and the cause may have appealed precisely because of her disgruntlement with the state Republican organization that had snubbed her, cutting short her political career.

A nother $\$ 150,000$ was supplied to the pro-198 forces in small donations (i.e. under $\$ 10,000$ each), with most of the balance coming from Hewlett Packard $(\$ 45,000$ directly, $\$ 300,000$ from David Packard, and $\$ 120,000$ from William Hewlett). In all, there was about a million dollars behind Proposition 198 , and only $\$ 100,000$ against it, $\$ 50,000$ having been given by Rupert Murdoch and $\$ 50,000$ having come directly from the state Republican party. ${ }^{14}$ Elite opposition, then, was not expressed financially, but in public statements and endorsements. The official "Argument Against Proposition 198" in the 1996 P rimary Voters' Handbook was, after all, signed by the chairmen of the California Republican and Democratic parties.

Despite official party opposition and strong elite antagonism at the rhetorical level, most of those who made their ways to the polls in March of 1996 endorsed the measure. Not only did 198 pass easily, it was one of six propositions (out of 12) that won majority support in every county of the state.15 Roughly $92.3 \%$ of all ballots featured a vote on 198, which was just slightly below the average participation rate $(92.7 \%)$ for that batch of propositions.

${ }^{14}$ All data on contribution amounts are taken from Jones (1996).

15 Unusually, all 12 propositions on the March 1996 ballot passed. 
Even before an open primary had been held under the new law, the state legislature was attempting to modify its key features. S.B. 1505, passed with little opposition in either house and then signed into law in July of 1998, placed Proposition 3 on the general-election ballot for the following November.16 That proposition would have reversed 198 with respect to presidential primaries by making voting for presidential convention delegates closed by party registration. The justification was that, under standing rules, both major national parties could exclude California delegations elected in a blanket primary in 2000 and thereafter.

The V oters' H andbook debate on Proposition 3 was even less balanced, in terms of prestige of the participants, than had been its 198 counterpart. United in favor of the modification were the senior State Senators from each party, the Assembly leaders of each party, and 198's old nemesis Bruce Herschensohn. Only first-term Assemblyman Jack Scott (D-44) opposed the proposition. And yet, perhaps because they were unconvinced that either major party would dare freeze the largest state out of its convention, whatever the formal rules specified, voters rejected Proposition 3 al most as unambiguously as their counterparts had supported 198 just 29 months earlier. Proposition 3 lost by a $54 \%$ to $46 \%$ margin, and won majority support in only one county (Los Angeles). The proposition was also ignored by an unusually large number of voters. Only $86.1 \%$ of all ballots included votes (pro- or con-) on the measure, giving it the fifth lowest participation rate of the 47 propositions considered by California voters in the 1996 and 1998 primary and general elections. ${ }^{17}$

\footnotetext{
16 It passed the Senate 35-0 on April 2 and passed in the Assembly 52-12 on July 10, 1998. Three days later the Senate concurred to Assembly amendments, 28-0, and July 13, 1998, it was signed by the Governor and chaptered by the Secretary of State.

17 Taking his cue from the $N$ ew Y ork Times (A yres 1998a, 1998b), Russell Hardin has proposed that the defeat of Proposition 3 exemplifies "astonishing" and "complete" misunderstanding by voters of "relatively simple issues" (1999, 10). One might equally contend that Hardin's analysis of Proposition 3 buttresses another of his claims, that "even professional political scientists, who have a strong interest in knowing more about politics...find it hard to keep up with much of what happens" (10). He mistakenly describes the open-primary law as "passed in ignorance of its consequences by the state legislature," apparently not realizing that, (a) the open-primary rules originated in direct democracy, and (b) did not apply only to presidential elections, so that "in ignorance of its consequences" cannot possibly be justified. He also claims that "administrative devices" put forth by a "knowledgeable bureaucratic agency" ultimately saved Californians from their own foolishness. His emphasis on bureaucracy is puzzling, since it was legislation passed after the failure of Proposition 3 that resolved the issue, by mandating double counting for presidential races, total votes and also own-party-registrant votes. And, since it
} 
The new legislature, however, was not willing to follow the voters' advice to play chicken with the national parties. Within months, both houses had passed a substitute for Proposition 3, again by overwhelming margins. When Governor Davis signed S.B. 100 into law in May of 1999, the state government had negated the impact of Proposition 198 with respect to presidential primaries. Since 1998 was not a presidential election year, all of these events concerning the rules for selecting presidential convention delegates were merely a sidebar in the first blanket-primary election year. In coming elections, though, the peculiar institutional fix now enshrined in law will offer useful data to political scientists.

Under the revised law, the presidential election appears to the voter to be open, since one can select delegates (in the minds of most voters, presidential candidates) without regard to one's own registration status. However, not all votes will be equal. It is now required of local election officials that they identify presidential ballots by the voter's party affiliation, so that they can perform a double tabulation. California's presidential convention delegates will be selected not according to the overall vote, but according to "the number of votes each delegate candidate receives from voters affiliated with the same political party as the delegate candidate." Whether one regards this revised law as a betrayal of the spirit of the blanket primary or a necessary corrective, a nice feature for political scientists is that the dual counting system allows recovery of directly observable evidence on cross-party voting. For most races, the study of voting behavior under the blanket will remain more complicated than the study of cross-over voting in the past, because the important vote totals must be estimated rather than simply read off of official returns. In presidential elections, though, the "faux-blanket" may introduce useful objective data. Depending on how well voters understand the complicated law, it could be that levels of cross-over in the presidential races will provide useful information about voter strategy and not simply noise and proof of ignorance.

\section{CONCLUSION}

Analysts eager to make predictions about how the arrival of the blanket primary system should change California elections have been looking to

was ultimately possible for the legislature to draft a law mandating a counting procedure that would survive party-rule scrutiny, it is plainly false that voting yes on Proposition 3 was somehow essential or the objectively right action for voters. It will remain an untested question whether either party would actually have dared to excludea California delegation at the risk of horrendous publicity in what is, by far, the nation's largest electoral prize. 
Washington and Alaska, the other two states with this variety of primary in place. They have entirely missed the clues buried in California's own electoral history and the natural link between the blanket primary and its ancestor, the multi-filing primary. The parallels are clearly numerous, and we have only begun to mine the wealth of data on how Californians behaved in past primaries, given the opportunity to vote outside of party registration lines.

There is clear evidence that the strategies behind cross-filing and crossover voting were not immediately obvious to Californians in the 1910s and 1920s. Though the Assembly saw a proliferation of "hyphenated," multiply nominated members immediately (see footnote 6), rates of cross-over voting did not rise dramatically until after a few elections had passed. We see no reason to expect modern-day voters and candidates to determine their optimal strategies under the blanket primary system any more quickly. Hence, a sub-theme for this entire book is that all conclusions should be qualified with a "so far." We await more evidence and further institutional tinkering, and we counsel continued attention to historical precedent as analysts struggle to understand Californians, their parties, and their primaries.

\section{REFERENCES}

Ayres, B. Drummond Jr. 1998a. "To Pick a President, Parties Must Part." N ew York Times (Monday August 3).

Ayres, B. Drummond Jr. 1998b. "If Primary Plan Loses, California May, Too." N ew Y ork Times (Tuesday November 3).

Ayres, B. Drummond Jr. 1999. "Senate Democrats Reach Outside Party." N ew York Times (Friday May 7).

Birtel, Marc. 1996. "Ballot: 'Jungle Primaries' Adopted...Reclassifying Lions Rejected." Congressional Q uarterly W eekly R eport 54, 13 (March 30): 902-903.

Block, A.G. and Claudia Buck (ed.s). 1997. California Political Almanac, 1997-1998, 5th Ed. Sacramento, CA: California Journal / State Net.

Brady, David W. and Brian J. Gaines. 1995. "A House Discarded? Evaluating the Case for a Unicameral California Legislature." In Bruce E. Cain and Roger G. Noll, eds. Constitutional Reform in California: M aking State Government M ore Effective and Responsive. Berkeley, CA: Institute of Governmental Studies Press, 195238. 
California Secretary of State (various). 1904-1964. Statement of V ote at Primary Election. Sacramento, CA: State Printing Office. (various volumes)

California Secretary of State (various). 1904-1964. Statement of V ote at General Election. Sacramento, CA: State Printing Office. (various volumes)

Davies, Lawrence E. 1951. "New Warren Term Starts Tomorrow." N ew York Times (Sunday January 7): 57.

Davies, Lawrence E. 1952. "Knowland Seeks California Sweep." N ew Y ork Times (Sunday May 4): 49.

Dubin, Michael J. 1998. U nited States Congressional Elections, 1788-1997. Jefferson, NC: McFarland \& Company, Inc., Publishers.

Gellman, Irwin F. 1999. The Contender: Richard N ixon, The Congress Y ears, 1946-1952. New York: Free Press.

Green, Stephen et al. 1995. California Political A Imanac 1995-1996, Fourth Edition. Sacramento, CA: California Journal Press.

Hardin, Russell. 1999. "Street-Level Epistemology and Political Participation." Invited Plenary Address to Public Choice Society, A nnual European Meetings, Lisbon.

Hichborn, Franklin. 1909. Story of the Session of the California Legislature of 1909. San Francisco, CA: Press of the James H. Barry Company.

Hichborn, Franklin. 1911. Story of the Session of the California Legislature of 1911. San Francisco, CA: Press of the James H. Barry Company.

Hichborn, Franklin. 1913. Story of the Session of the California Legislature of 1913. San Francisco, CA: Press of the James H. Barry Company.

Hichborn, Franklin. 1915. "The System" As U ncovered By the San Francisco Graft Prose cution. San Francisco, CA: Press of the James H. Barry Company.

Hichborn, Franklin. 1916. Story of the Session of the California Legislature of 1915. San Francisco, CA: Press of the James H. Barry Company.

Hichborn, Franklin. 1922. Story of the Session of the California Legislature of 1921. San Francisco, CA: Press of the James H. Barry Company.

Hill, Gladwin. 1959a. "California Bills Rushed By Brown." N ew Y ork Times (Sunday January 18): 64.

Hill, Gladwin. 1959b. “Cross-Filing Ban In Peril on Coast." N ew Y ork Times (M onday March 16): 15.

Hill, Gladwin. 1959c. "California Shift Will Help Voter." N ew Y ork Times (Sunday A pril 26): 67.

Jones, Bill (Secretary of State of California). 1996. Financing California's Statewide Ball ot M easures: 1996 Primary and General Elections Campaign Receipts and Expenditures 
Through June 30, 1996. Sacramento, CA: Secretary of State, Political Reform Division.

Kettl, Donald F. 1992. D eficit Politics: Public Budgeting in Its Institutional and $\mathrm{H}$ istorical Context. New York, NY: MacMillan Publishing Company.

Laakso, Markku and Rein Taagepera. 1979. “'Effective' Number of Parties: A Measure with Application to Western Europe." Comparative Political Studies 12, 1 (A pril): 3-27.

Lee, Eugene C. 1960. The Politics of $\mathrm{N}$ on partisanship: A Study of California City Elections. Berkeley, CA: University of California Press.

no author. 1959a. "Coast Rivals A gree." N ew Y ork Times (Saturday February 28): 7.

no author. 1959b. "Legislature Repeals Cross-Filing in State: Signature of Governor Assured." Los A ngeles Times (Friday A pril 24): 1.

Shannon, Don. 1959. "Repeal of Cross-Filing Hailed By Congressmen." Los A ngeles Times (Saturday A pril 25): 4.

State of California. 1920. State of California Direct Primary Law with the O fficial Forms Prepared by the Secretary of State and the A ttorney General. Sacramento, CA: State of California Printing Office.

Young, C.C. (ed). 1943. The Legislature of California: Its M embership, Procedure, and W ork. San Francisco, CA: Press of the Parker Printing Company. 